\title{
Immunological Evaluation of Human Immunedeficiency Virus Infected Individuals by Flow Cytometry
}

\author{
I Neves Jr, MG Morgado ${ }^{+}$ \\ Laboratório de Aids e Imunologia Molecular, Departamento de Imunologia, Instituto Oswaldo Cruz, \\ Centro Colaborador da Unaids, Av. Brasil 4365, 21045-900 Rio de Janeiro, RJ, Brasil
}

Human immunodeficiency virus (HIV) infection heavily compromises the immune system. The decrease of the T cell CD4+ subset along the evolution to acquired immunodeficiency syndrome has been considered as a hallmark of HIV infection. In this paper we review some aspects of the immunopathology of HIV infection and discuss the importance of the flow cytometry for the evaluation of the Tlymphocyte subsets in the follow-up of HIV infected children and adults, and for the monitoring of the immune reconstitution upon antiretroviral therapy.

Key words: human immunodeficiency virus/acquired immunodeficiency syndrome (HIV/Aids) - T lymphocyte subsets - flow cytometry

\section{HIV INFECTION}

The human immunodeficiency virus (HIV) infection heavily compromises the immune system leading to opportunistic infections, neoplasias and neurological commitments. The drop of the T cell $\mathrm{CD}^{+}$subset along the evolution to acquired immunodeficiency syndrome (Aids) is a hallmark of HIV infection. Indeed, this major alteration of the immune system was quickly associated with the clinical observations permitting the staging of the patients along the evolution to Aids. The $\mathrm{CD}^{+}{ }^{+} \mathrm{T}$ lymphocyte counts has been considered as a surrogate marker for disease progression, as well as for the antiretroviral therapy and prophylaxis for opportunistic pathogens (Stites et al. 1989, Bogner \& Goebel 1991, Fauci 1993). Moreover, the CD4 ${ }^{+}$ T lymphocyte counts may also be used as surrogate markers of HIV infection in patients who have delays in HIV serologic reporting or have refused to test. There are relatively few conditions associated with the profound depletion of this T cell subset in patients who have the classical "Aids-defining diagnoses", included in their differential diagnosis (reviewed by Bartlett 1998). More recently, the viral load measurement was introduced to the routine laboratorial evaluation of HIV infected individuals and this parameter was shown to be of paramount importance to predict time to Aids or death, which increase with a steeper CD4 decline and a higher viral burden (Mellors et al. 1996,

\footnotetext{
${ }^{+}$Corresponding author. Fax: + 55-21-280.1589. E-mail: morgado@gene.dbbm.fiocruz.br

Received 9 August 1999

Accepted 24 January 2000
}

1997, Fahey et al. 1998).

At least four profiles can be distinguished among HIV infected people concerning the progression to disease (Fauci 1993, Pantaleo \& Fauci 1996). The majority of them (70-80\%) progress to Aids in five to ten years (typical progressors), with progressive loss of $\mathrm{CD}^{+} \mathrm{T}$ lymphocyte and immune functions and persistent virus replication. In a small percentage, some individuals progress within a period similar to the typical progressors, but the clinical, immunological and virological parameters remain stable for a longer period of time (long-term survivors). Another significant percentage of individuals (10-15\%), however, rapidly progresses to Aids and death within the first 2-3 years after seroconvertion (rapid progressors). On the other hand, a small percentage (less than 5\%) do not experience the typical loss of $\mathrm{CD}^{+} \mathrm{T}$ lymphocytes over an extended period of time and are described as long-term nonprogressors. The HIV positive individuals included in this group have low levels of virus, and preservation of lymphoid tissue architecture and immune functions. Although the mechanisms favoring one or another type of progression are not completely clarified, host genetic profile, immune responses, as measured, for example, by the $\mathrm{T}$ cell repertoire usage (Pantaleo et al. 1994, 1997, Graziosi et al. 1998) or the cytokines and chemokines production and regulation (Cohen et al. 1997), as well as the virus biological and genetical profiles are certainly contributing to the distinct patterns of progression (reviewed by Fauci 1996).

The recent advent of potent antiretroviral combination therapy, inducing profound and rapid falls in the levels of plasma virus, has been changing the course of Aids, and giving a new insight for 
controlling the progression to disease. However, discontinuation of antiretroviral therapy after short or prolonged (Stellbrick et al. 1996, Finzi et al. 1997, Connors et al. 1997) treatment of chronically infected patients, keeping plasma viral load below detectable levels, results in rapid increase of viremia, indicating persistent active virus replication even in the presence of the drugs.

\section{FLOW CYTOMETRY AND HIV INFECTION}

Although the laboratorial hallmark of the evolution of HIV infection is the T cell $\mathrm{CD}^{+}{ }^{+}$subset reduction over time, functional studies have demonstrated qualitative impairment of the $\mathrm{CD}^{+} \mathrm{lym}$ phocyte functions occurring early in the course of infection, even before its quantitative decrease (Rosenberg \& Walker 1998). Indeed, CD4 ${ }^{+}$helper $T$ cell responses are known to be essential for maintenance of the effective immunity in chronic viral infections and the hierarchical loss of the $\mathrm{CD} 4^{+}$ functional activity, measured both by the reduction in the lymphoproliferative response and the IL-2 secretion, has been demonstrated in HIV-1 infected patients even before Aids onset (Clerici et al. 1989). In a first stage, loss of T cell response to common recall antigens (FLU, TT), followed by alloantigens and mitogens can be prospectively observed, however, these methodologies are very time consuming and need special laboratory facilities for the monitoring of HIV infected patients.

The development of a system permitting the automatic count of particles suspended in a fluid was patented in 1949 (Coulter 1949), and it took almost twenty years to evolve to a computer assisted multiparametric flow cytometric data analysis system (Dittrich \& Gohde 1968), which has achieved paramount importance within the range of clinical pathology procedures and research applications.

Flow cytometry is the standard method for determining $\mathrm{CD}^{+} \mathrm{T}$ lymphocytes counts in order to monitor HIV infection. Associated with the usage of specific monoclonal antibodies labeled with several available fluorocromes, this methodology permits a specific and fast semi-automatic quantification of cellular subsets, and the processing and reading of several samples in a short time. Other alternative methodologies have also been developed over time, like (a) the FACS Count System (Becton Dickinson Immunocytometry Systems), (b) VCS Technology/Coulter Cyto-Spheres (Coulter Corporation), (c) Zymmune CD4/CD8 Cell Monitoring Kit (Zynaxis, Inc) and (d) TRAx CD4 Test Kit (T Cell Diagnostics), which present a good performance when compared with standard flow cytometry and require less technical expertise (Johnson et al. 1995). However, different from standard flow cytometry, these alternative systems are only restricted to the $\mathrm{CD}^{+}$and $\mathrm{CD} 8^{+} \mathrm{T}$ lymphocyte subsets quantification.

The advance of the flow cytometry for two, three or four-color systems allowed the analysis of distinct surface molecules in a single cell, leading to more accurate evaluation of specific cell subsets. A typical panel composed of fluorescein isothiocianate (FITC) and phycoerytrin (PE/RD1) labeled monoclonal antibodies is among the most frequently used for routine analysis for the monitoring of the HIV infection. Current standards use multiple tube assay including $\mathrm{CD} 45^{+} / \mathrm{CD} 14^{+}$as gating control, isotype control, $\mathrm{CD}^{+} / \mathrm{CD}^{+}$and $\mathrm{CD}^{+} / \mathrm{CD}^{+}$double labeled monoclonal antibodies (CDC 1994).

The technical improvement for the three-color system, using the combination of PerCP (peridinin chlorophyll protein), FITC and PE labeled monoclonal antibodies allows the determination, for example, of the $\mathrm{CD}^{+} / \mathrm{CD}^{+}, \mathrm{CD}^{+} / \mathrm{CD}^{+}$subsets and the total $\mathrm{CD}^{+}$in a single tube (Fig. 1). In this case, the lymphocyte region is determined based on the side scatter (SS) and forward scatter (FS) histogram. Moreover, with the four-color staining system, the leucogate histogram can be based on the $\mathrm{SS}$ and the FITC labeled CD45 ${ }^{+}$and the T cell subsets are immunophenotyped using $\mathrm{CD}^{+}-\mathrm{PC} 5$, $\mathrm{CD} 8^{+}$-ECD (phycoerythrin-Texas Red) and $\mathrm{CD}^{+}{ }^{+}$ RD1 labeled monoclonal antibodies in a single tube assay (Fig. 2). In this case, the lymphocytes are phenotyped as low granulated CD45 ${ }^{\text {bright }}$ expressing cells. In addition to the higher accuracy of these three or four-color systems, one other advantage is the low quantity of blood employed ( $100 \mu \mathrm{l} /$ assay), which is very relevant for Aids pediatrics, as well as for multiple immunological and virological analysis of HIV positive individuals combining routine exams and research purposes.

Due to the several aspects that can interfere in the flow cytometric analysis of the $\mathrm{T}$ cell subsets of HIV infected individuals, it is of paramount importance to establish quality control procedures in order to guarantee the accuracy of the final results. Another important issue with regard to cytometry assay with specimens from HIV-infected individuals is biohazard considerations. For the protection of the cytometryst, specimens can be fixed with a $1 \%$ solution of formaldehyde or paraformaldehyde, and the waste container system should be used with a final concentration of $1 \%$ sodium hypochlorite in order to inactivate the HIV.

\section{CD4 $^{+}$T CELL INTERPRETATION}

Age dependent differences have been described for the $\mathrm{CD} 4^{+} \mathrm{T}$ cell count analysis, and this variation has to be taken into consideration for prophy- 
lactic and antiretroviral therapies of HIV infected individuals.

For adults and adolescents the normal values of $\mathrm{CD} 4^{+} \mathrm{T}$ lymphocytes in the bloodstream vary from $800-1050 / \mathrm{mm}^{3}$, with a range representing two standard deviations of approximately 500 to
$1400 / \mathrm{mm}^{3}$ (Laurence 1993). Such variability reflects the variables used for the $\mathrm{CD}^{+}{ }^{+} \mathrm{T}$ lymphocyte determination which takes into account the leukocyte counts, the percentage of lymphocytes and the percentage of lymphocytes that bear the $\mathrm{CD}^{+}$and $\mathrm{CD}^{+}{ }^{+}$receptors. Seasonal, month-to-

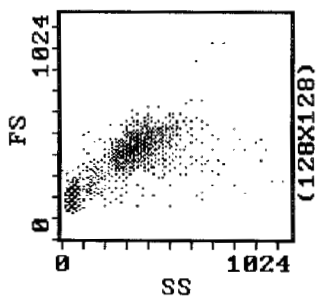

5:

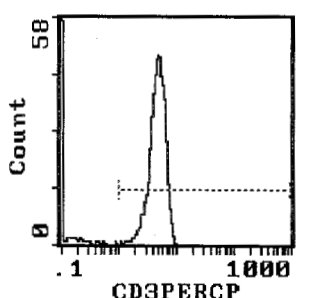

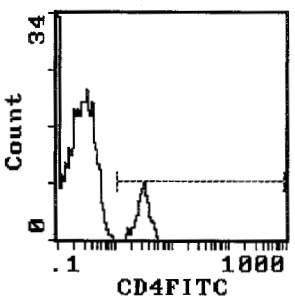

6: A

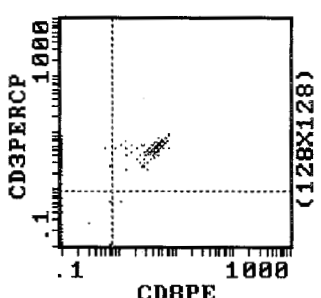

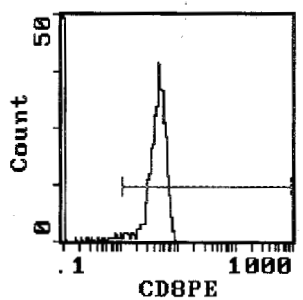

7:

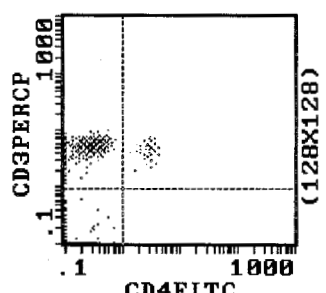

Fig.1: three color cell surface marker analysis. The triple color analysis indicates the CD3, CD3/CD4 and CD3/CD8 lymphocyte subsets from an human immunodeficiency virus (HIV)-positive individual. One hundred microlitres of whole blood was incubated for $30 \mathrm{~min}$ at room temperature in the dark with $10 \mu \mathrm{l}$ of monoclonal antibodies (Tritest CD4FITC/CD8PE/CD3PerCP, Becton Dickinson CO, USA) and automatically lysed and fixed using a Multi-Q-Prep system, according to the manufacturer (Coulter Corp., Healeah, Fl, USA). The T cell subset determinations were carried out using an EPICS XL-MCL Flow Cytometer (Coulter Corp., Healeah, Fl, USA).

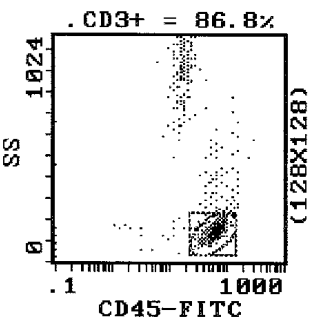

4: 80

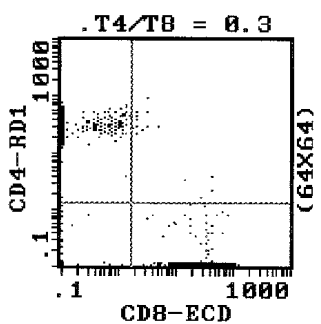

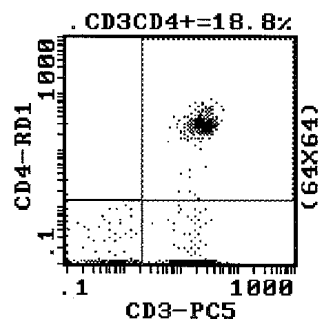

5:

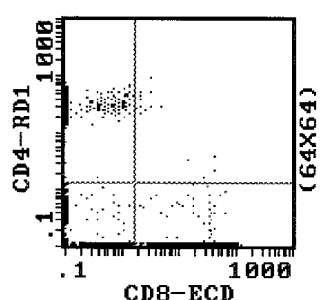

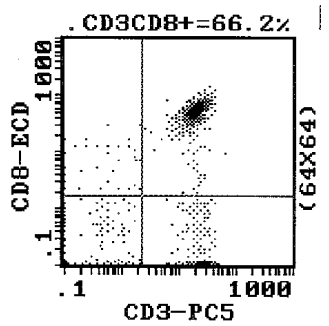

6: $\mathbb{B}$

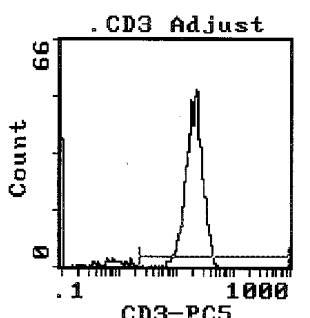

Fig. 2: four color cell surface marker analysis. The four color analysis indicates the CD45, CD3, CD3/CD4 and CD3/CD8 lymphocyte subsets from an human immunodeficiency virus (HIV)-positive individual. One hundred microlitres of whole blood was incubated for $30 \mathrm{~min}$ at room temperature in the dark with $10 \mu \mathrm{l}$ of monoclonal antibodies (Cyto-Stat tetraCHROME, CD45FITC/ CD4RD1/CD8ECD/CD3PC5, Coulter Co, Miami, FL, USA) and automatically lysed and fixed using a Multi-Q-Prep system, according to the manufacturer (Coulter Corp., Healeah, Fl, USA). The filters used for the four-color analysis were $525 \mathrm{BP}, 575$ $\mathrm{BP}, 620 \mathrm{BP}, 675 \mathrm{BP}$ and the T cell subset determinations were carried out using an EPICS XL-MCL Flow Cytometer (Coulter Corp., Healeah, FL, USA). 
month and diurnal changes in the $\mathrm{CD}^{+} \mathrm{T}$ lymphocyte counts have been described in healthy adults (van Rood et al. 1991), whereas factors like gender, age in adults, risk category, psychological or physical stress and pregnancy have minimal effects on the $\mathrm{CD}^{+}{ }^{+} \mathrm{T}$ lymphocyte counts (reviewed by Bartlett 1998).

The revised CDC (Centers for Disease Control and Prevention) classification system for HIV-infected adolescents and adults (CDC 1993) is based on the clinical conditions and the $\mathrm{CD}^{+}{ }^{+} \mathrm{T}$ lymphocyte counts. This system is represented by a matrix of nine categories (A1 to C3) based on the combination of three levels of $\mathrm{CD}^{+} \mathrm{T}$ lymphocyte counts $\left(1 .>500 / \mathrm{mm}^{3} ; 2.200-499 / \mathrm{mm}^{3} ; 3\right.$. $<200 / \mathrm{mm}^{3}$ ) and three clinical categories (A, B and C). Asymptomatic HIV infection, persistent generalized lymphadenopathy and acute HIV infection are included in category $\mathrm{A}$, whereas distinct associated diseases are included in the categories $\mathrm{B}$ and $\mathrm{C}$.

The Advisory Group on Antiretroviral Therapy of the Brazilian STD/Aids Program (Ministério da Saúde 1998) has also established a system to categorize HIV infected individuals in order to recommend initiation of antiretroviral and prophylactic therapy in the country, as well as the therapeutic regime to be applied depending on the clinical, immunological and virological conditions. Brazil is one of the few countries in the world offering antiretroviral and prophylactic treatment, as well as monitoring exams as $\mathrm{CD} 4^{+} \mathrm{T}$ lymphocyte counts and viral load measurement for HIV infected individuals. Table I shows the clinical, immunological and virological criteria considered for the recommendation of initiating antiretroviral and prophylactic treatment of HIV infected adults and adolescents in the country.

The $\mathrm{CD}^{+} \mathrm{T}$ lymphocyte counts in young healthy children (less than 5 years old) are higher than adults, varying from around $3,000 / \mathrm{mm}^{3}$ at 6 months old to $2,500 / \mathrm{mm}^{3}$ and $1,500 / \mathrm{mm}^{3}$, respectively, at 12 and 24 months old (Erkeller-Yuksel et al. 1992). Similar values to adults can be achieved in children who are 6 years old or more, and this normal decay in the CD4+ T lymphocyte population in younger children has to be taken into consideration for the analysis of the immune alterations in Aids pediatrics. Indeed, the CDC classification for Aids pediatrics is based both in the clinical signs and symptoms (N: without signs and symptoms; $\mathrm{A}, \mathrm{B}$ and C, respectively, light, moderate and severe signs and symptoms) and the immunological alterations, defined as absent (1), moderate (2) and severe (3), based on the $\mathrm{CD} 4^{+} \mathrm{T}$ lymphocyte counts (CDC 1994). Table II presents these levels of immunological alterations considered for HIV-infected children ( $0-12$ years old). Similarly to what has been described for adults and adolescents, this system classification is represented by a matrix of twelve categories (N1 to C3) based on clinical and immunological parameters. The STD/Aids Pro-

TABLE I

Recommendations of the Brazilian STD/Aids Program for initiating therapy of human immunodeficiency virus (HIV) infected adults and adolescents

\begin{tabular}{|c|c|c|c|}
\hline Clinical situation & $\begin{array}{l}\text { CD4 } \\
\left(\text { cells } / \mathrm{mm}^{3}\right) \\
\text { cytometry }\end{array}$ & $\begin{array}{l}\text { Count viral load } \\
\text { (copies/ ml) flow }\end{array}$ & Recommendation \\
\hline Asymptomatic & Not available & Not available & No treatment \\
\hline Asymptomatic & $\geq 500$ & $\begin{array}{l}\text { 1. }<100.000 \\
\text { 2. } \geq 100.000 \\
\text { 3. Viral load not available }\end{array}$ & $\begin{array}{l}\text { 1. No treatment } \\
\text { 2. Consider treatment } \\
\text { 3. No treatment }\end{array}$ \\
\hline Asymptomatic & $\geq 350<500$ & $\begin{array}{l}\text { 1. }<30.000 \\
\text { 2. } \geq 30.000 \\
\text { 2. Treat }\end{array}$ & 1. Consider treatment \\
\hline Asymptomatic & $\geq 200<350$ & $\begin{array}{l}\text { 1. }<30.000 \\
\text { 2. } \geq 30.000\end{array}$ & $\begin{array}{l}\text { 1.Treat } \\
\text { 2. Treat }\end{array}$ \\
\hline Asymptomatic & $<200$ & Irrespective of viral load & $\begin{array}{l}\text { Initiate therapy and prophylaxis } \\
\text { for opportunistic infections }\end{array}$ \\
\hline
\end{tabular}

Whenever there are no CD4 cell counts or viral load evaluations available, use of antiretrovirals is recommended for symptomatic patients only, except for special situations: pregnant HIV-infected women, newborn of HIV-positive mother and occupational exposure to HIV. Adapted from the guidelines for clinical treatment of HIV infection in adults and adolescents, 1999, National Coordination of STD and Aids, Brazilian Ministry of Health, in portuguese. (http://www.Aids.gov.br) for updating. 
TABLE II

Immunological categories of human immunodeficiency virus (HIV)-infected children based on age and CD4 ${ }^{+} \mathrm{T}$ lymphocyte counts $/ \mathrm{mm}^{3}$ of peripheral blood

\begin{tabular}{llll}
\hline Immunological & \multicolumn{3}{c}{$\begin{array}{c}\text { Age } \\
\text { CD4 }\end{array}$} \\
\cline { 2 - 4 } alterations & \multicolumn{1}{c}{ (12 months } & 1 to 5 years old & 6 to 12 years old \\
\hline Absent (1) & $>1,500(>25 \%)$ & $>1,000(>25 \%)$ & $>500(>25 \%)$ \\
Moderate (2) & $750-1,499(15-24 \%)$ & $500-900(15-24 \%)$ & $200-499(15-24 \%)$ \\
Severe (3) & $<750(<15 \%)$ & $500(<15 \%)$ & $<200(<15 \%)$ \\
\hline
\end{tabular}

CDC (1994), reproduced from the guideline for clinical treatment of HIV infection in children, 1998, National Coordination of STD and Aids, Brazilian Ministry of Health, in portuguese; http://www.aids.gov.br for updating.

gram from the Brazilian Ministry of Health use this system to base the consensus recommendation for antiretroviral therapy in HIV infected children (guideline for clinical treatment of HIV infection in children, 1998, National Coordination of STD and Aids, Brazilian Ministry of Health, in Portuguese).

\section{CD8 $^{+}$LYMPHOCYTES AND HIV INFECTION}

The importance of the $\mathrm{CD} 4^{+} \mathrm{T}$ lymphocyte counts has been rapidly incorporated to the clinical and laboratorial monitoring of HIV infected people, however the evaluation of other subsets of T lymphocytes, characterized by a wide panel of monoclonal antibodies already available, which could delineate in a better extent the immunological status of HIV infected individuals, is still restricted to research protocols.

Changes in the $\mathrm{CD}^{+} \mathrm{T}$ lymphocytes subsets, associated with progressive inversion in the $\mathrm{CD}^{+} /$ $\mathrm{CD}^{+}$ratio have been studied as markers of disease progression in HIV infected people (Ferbas 1998). Increase in the absolute number of $\mathrm{CD}^{+} \mathrm{T}$ lymphocyte over time is a well known event and is not correlated with reduction on viral load. Moreover, increased expression of $\mathrm{CD}^{+} 8^{+}$and HLA$\mathrm{DR}^{+}$cell activating markers in $\mathrm{CD}^{+} \mathrm{T}$ lymphocytes from HIV infected people progressing to Aids has also been described (Kestens et al. 1992). Fig. 3 is representative of the evaluation of $\mathrm{CD}^{+} /$ $\mathrm{CD} 8^{+} \mathrm{T}$ cell activated lymphocytes, using a twocolor panel with $\mathrm{CD}^{+}{ }^{+}$-FITC and CD38 ${ }^{+}$-PE labeled monoclonal antibodies (Neves $\mathrm{Jr}$ et al. unpublished observations). The HIV-1 seropositive individuals included in this study are being analyzed before and after the introduction of the highly active antiretroviral therapy (HAART), in order to evaluate its effect on T cell activation and apoptosis (data not shown), among other clinical, immunological and virological parameters. Reduction on the $\mathrm{CD}^{+} \mathrm{T}$ cell subset during antiretroviral therapy has been previously documented (Autran et al. 1997), including a decrease on the CD38 expres- sion on $\mathrm{CD}^{+}{ }^{+}$lymphocytes (Bouscarat et al. 1998). However, undetectable plasma HIV RNA is not associated with a return to normal $\mathrm{CD}^{+}$lymphocyte activation status even after six months of treatment, suggesting that viral replication persist in lymphoid tissues.

The presence of virus-specific $\mathrm{CD}^{+}$cytotoxic T lymphocytes (CTLs) can be detected during early HIV infection and has been correlated with downregulation of viremia after the acute viral syndrome (Walker \& Levy 1989). Moreover, in addition to regulatory and pro-inflamatory cytokines, $\mathrm{CD}^{+} \mathrm{T}$ lymphocytes release $\beta$ chemokynes, as RANTES, MIP- $1 \alpha$ and MIP1- $\beta$, which are the natural ligants of the CCR5 coreceptor for virus cell entry (Cocchi et al. 1995, Deng et al. 1996, Dragic et al. 1996, Alkhatib et al. 1996), as well as the cell activating factor, CAF (Levy et al. 1996), described as a soluble factor

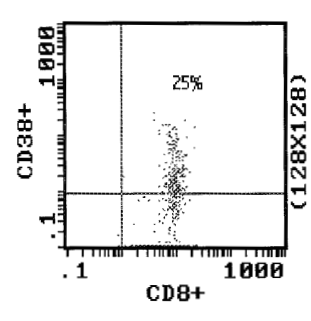

HIV-POSITIVE

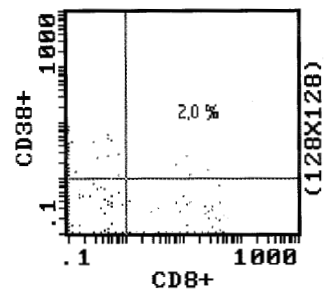

CONTROL
Fig. 3: phenotyping changes of CD8 lymphocytes during human immunodeficiency virus (HIV)-1 infection. Three-color flow cytometric analysis shows high expression of the activation marker CD38 on CD3/CD8 T lymphocytes from an HIV positive individual compared to a normal control. One hundred microlitres of whole blood was incubated for $30 \mathrm{~min}$ at room temperature in the dark with $10 \mathrm{ml}$ of the monoclonal antibodies CD3FITC/CD8RD1 (Coulter Corp., Healeah, FL, USA) and CD38Cy-Chrome (Pharmigen, CA, USA) and automatically lysed and fixed using a Multi-Q-Prep system, according to the manufacturer (Coulter Corp., Healeah, FL, USA). The T cell subset determinations were carried out using an EPICS XLMCL Flow Cytometer (Coulter Corp., Healeah, FL, USA). 
inhibitor for in vitro virus replication in HIV-infected $\mathrm{CD}^{+}{ }^{+} \mathrm{T}$ cells. Therefore, $\mathrm{CD} 8^{+} \mathrm{T}$ lymphocytes are important anti-viral components in the immunopatology of HIV infection.

\section{ANALYSIS OF CELLULAR DEATH IN HIV INFECTION}

The suicide programmed cell death, called apoptosis occurs under different physiological and pathological conditions. In HIV infection apoptosis has been widely described along the progression to Aids in freshly obtained peripheral blood lymphocytes or purified cells upon antigenic or mitogenic stimulation, affecting both $\mathrm{CD}^{+}$and $\mathrm{CD} 8^{+}$ $\mathrm{T}$ lymphocyte subsets (reviewed by Ameisen 1994). Indeed, apoptosis in HIV infected individuals in an early marker occurring independently of high viremia (Rothen et al. 1997). More recently, significant decrease in apoptosis of lymphoid tissue (Badley et al. 1998), and in the memory T cell subset (Gougeon et al. 1999), has been observed in HIV infected individuals submitted to HAART. The analysis of cellular death can be determined by several approaches. Flow cytometric analysis of the propidium iodide stained lymphocytes can easily be performed to determine cell death and cellular cell cycle (Fig. 4), where the degree of fluorescence represents the amount of the DNA, which varies along the cell cycle (Braylan et al. 1982, Hamel et al. 1996, Neves Jr et al. 1998). Although the simultaneous PI and cell surface labeling has been described (Garvy et al. 1993), this method could be used with precaution, regarding the lost of cell membrane integrity. The 7-aminoactinomicin (7-aad), however, is an alternative DNA dye which allows the discrimination of apoptosis and necrosis in cell populations (Rabinovitch et al. 1986). Moreover, it is possible to combine a three-color system, including 7-aad staining associated with specific PE and FITC labeled cell surface monoclonal antibodies, permitting the discrimination among the targeted cells (Schmid et al. 1992). In addition, the HO342 (Bisbenzimidazole), a vital dye for identification of live and apoptotic cells, is a third alternative dye, giving similar results of 7-aad in the apoptosis determination (Schmid et al. 1994). However, these techniques should not be taken as definite evidence for the presence of apoptotic cell population without other supporting information. Apoptosis, possibly mediated through the CD95 antigen, has been proposed as a mechanism for cell loss, which eventually leads to immune dysfunction. Increased $\mathrm{CD} 95^{+}$expressing $\mathrm{CD} 4^{+}$and $\mathrm{CD} 8^{+} \mathrm{T}$ cell subsets have been observed in HIV-infected individuals (Aries et al. 1995, McCloskey et al. 1995, 1998, Baumler et al. 1996). Taken together, these data suggest that flow cytometric analysis of apoptosis
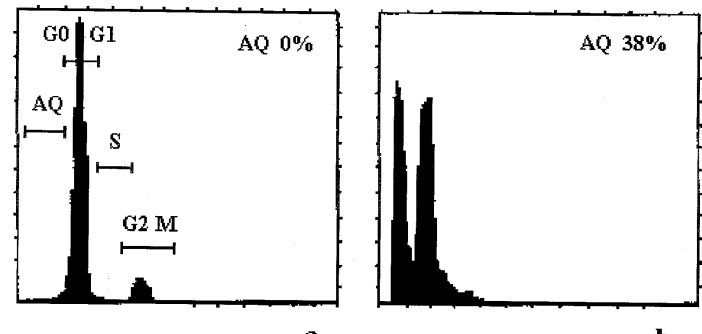

a

Fig. 4: flow cytometric analysis of cell cycle and programed cell death (apoptosis). Cell cycle was determined for propidum iodide (PI) stained PBMC, incubated with (a) culture medium and (b) phytohemaglutinin, obtained from an human immunodeficiency virus (HIV)-positive patient. Determination of cell cycle distribution was carried out using an EPICS 751 Flow Cytometer (Coulter Corp., Healeah, FL, USA). Apoptotic cells were determined based on the appearance of a peak in the subG0G1 region (b). From Neves Jr et al. (1998).

could also be included for the monitoring of the immune system in HIV infected individuals.

\section{FINAL REMARKS}

The recent introduction of combined highly active antiretroviral therapy has substantially reduced the viral load in most HIV infected people. Indeed, increase in the $\mathrm{CD}^{+}{ }^{+} \mathrm{T}$ lymphocyte levels, associated with the reduction of plasma viral load, have been thoroughly described in people submitted to HAART (Autran et al. 1997, 1999, Lefeuillade et al. 1997, Pantaleo 1997), presenting new questions about the potential of the reconstitution of the immune system of HIV infected individuals with distinct levels of immunosupression. In this field, flow cytometry is the methodology of choice, permitting the evaluation of several cell populations, as well as their proliferating capacity and cytokine secretion patterns (Landay et al. 1990, Krouwels et al. 1997), among other applications.

Moreover, several other applications of flow cytometry can also be depicted in the HIV/Aids field. Evaluation of seroreactivity to HIV antigens adsorbed to beads (immunoreactive bead assay), as well as the qualitative and quantitative analysis of HIV infected cells by means of the detection of p24 antigen in peripheral blood mononuclear cells, using specific monoclonal antibodies, are examples of these possibilities. A recent description of flow cytometry to evaluate the presence and specificity of cytotoxic $\mathrm{T}$ cells based on their reactivity to human leukocyte antigen-peptide tetrameric complexes (Ogg et al. 1998) open a new and powerful field for the monitoring of HIV infected patients, as well as for the evaluation of the cell mediated immunity induced by the HIV/Aids vaccines under analysis. 


\section{REFERENCES}

Aires SP, Schaaf B, Muller RH, Dalhoff K 1995. Fas (CD95) expression on $\mathrm{CD}^{+}$cells from HIV-infected patients increases with disease progression. $\mathrm{J} \mathrm{Mol}$ Med 73: 591-593.

Alkhatib G, Combadiere C, Broder CC, Feng Y, Kennedy PE, Murphy PM , Berger EA 1996. CC CKR5: A RANTES, MIP- $1 \alpha$, MIP- $1 \beta$ receptor as a fusion cofactor for macrophage-tropic HIV-1. Science 272: 1955-1958.

Ameisen JC 1994. Programmed cell death (apoptosis) and cell survival regulation: relevance to Aids and cancer. Aids 8: 1197-1213.

Autran B, Carcelaint G, Li TS, Blanc C, Mathez D, Tubiana R, Katlama C, Debre P, Leibowitch J 1997. Positive effects of combined antiretroviral therapy on $\mathrm{CD}^{+}{ }^{+}$homeostasis and function in advanced HIV disease. Science 277: 112-116.

Autran B, Carcelaint G, Li TS, Gorochov G, Blanc C, Renaud M, Durali M, Mathez D, Calvez V, Leibowitch J, Katlama C, Debre P 1999. Restoration of the immune system with anti-retroviral therapy. Immunol Lett 66: 207-211.

Badley AD, Dockrell DH, Algeciras A, Ziemer S, Lederman MM, Connick E, Kessler H, Kuritzkes D, Lynch DH, Roche O, Yagita H, Paya CV 1998. In vivo analysis of FAS/FasL interaction in HIV-infected patients. J Clin Invest 102: 79-87.

Bartlett JG 1998. Medical Management of HIV Infection. Port City Press, Baltimore.

Baumler CB, Bohler T Herr I Benner A, Kraummer PH, Debatim KM 1996. Activation of the CD95 (APO$1 /$ FAS) system in the cells from human immunodeficiency virus type-1 infected children. Blood 88 : 1741-1746.

Bogner JR, Goebel FD 1991. Lymphocyte subsets as surrogate markers in antiretroviral therapy. Infection 19: S103-108.

Bouscarat F, Levacher M, Landman R, Muffat-Joly M, Girard P-M, Saimot AG, Brun-Vézinet F, Sinet M 1998. Changes in blood CD8 ${ }^{+}$lymphocyte activation status and plasma HIV RNA levels during antiretroviral therapy. Aids 12: 1267-1273.

Braylan RC, Bensen NA, Nourse V, Kruth HS 1982. Correlated analysis of cellular DNA, membrane antigens and light scatter of human lymphoid cells. Cytometry 2: 337-343.

CDC-Centers for Disease Control 1993. Revised classification system for HIV infection and expanded surveillance case definition for Aids among adolescents and adults. $M M W R$ 41: 1-13.

CDC-Centers for Disease Control 1994. Revised classification system of human immunodeficiency virus infection in children less than 13 years of age. MMWR 43: 1-10.

Clerici M, Stocks NI, Zajac RA, Boswell RN, Lucey DR, Via CS, Shearer GM 1989. Detection of three distinct patterns of $\mathrm{T}$ helper cell dysfunction in asymptomatic, human immunodeficiency virus- seropositive patients. Independence of $\mathrm{CD}^{+}$cell numbers and clinical staging. J Clin Invest 84:1892-1899.

Cocchi F, DeVico AL, Garzino-Demo A, Arya SK, Gallo
RC, Lusso P 1995. Identification of RANTES, MIP$1 \alpha$ and MIP-1 $\beta$ as the major HIV-supressive factors produced by $\mathrm{CD}^{+} \mathrm{T}$ cells. Science $270: 1811-1815$.

Cohen OJ, Kinter A, Fauci AS 1997. Host factors in the pathogenesis of HIV disease. Immunol Rev 159: 31-48.

Connors M, Kovacs JA, Krevat S, Gea-Banacloche JC, Sneller MC, Flanigan M, Metcalf JA, Walker RE, Falloon J, Baseler M, Feuerstein I, Masur H, Lane HC 1997. HIV infection induces changes in CD4 ${ }^{+} \mathrm{T}-$ cell phenotype and depletions within the $\mathrm{CD} 4^{+} \mathrm{T}$-cell repertoire that are not immediately restored by antiviral or immune-based therapies. Nat Med 3: 533-40.

Coulter WH 1949. U.S. Patent No. 2.656.508. Means for counting particles suspended in a fluid. Filed 27 Aug, 1949. Issued 20 Oct.

Deng H, Liu R, Ellmeier W, Choe S, Unutmaz D, Burkhart D, Di Marzio P, Marmom S, Sutton RE, Hill CM, Davis CB, Peiper SC, Schall TJ, Littman DR, Landau NR 1996. Identification of a major co-receptor for primary isolates of HIV-1. Nature 381: 661-666.

Dittich W, Göhde W 1968. British Patent No. 1.300.585. Automatic measuring and counting device for particles in a dispersion. Filed Germany, 18 Dec. 1968. Issued 20 Dec.

Dragic T, Litwin V, Allaway GP, Martin SR, Huang Y, Nagashima KA, Cayanan C, Maddon PJ, Koup RA, Moore JP, Paxton WA 1996. HIV-1 entry into CD4 ${ }^{+}$ cells is mediated by the chemokine receptor CCCKR-5. Nature 381: 667-673.

Erkeller-Yuksel FM, Deneys V, Yuksel B, Hannet I, Hulstaert F, Hamilton C, Mackinnon H, Turner Stokes L, Munhyeshuli V, Vanlangendonck F 1992. Age-related changes in human blood lymphocyte subpopulations. J Pediatrics 120: 216-222.

Fahey JL, Taylor JM, Manna B, Nishanian P, Aziz N, Giorgi JV, Detels R 1998. Prognostic significance of plasma markers of immune activation, HIV viral load and CD4 T-cell measurements. Aids 12: 1581-1591.

Fauci AS 1993. Multifactorial nature of human immunodeficiency virus disease: implications for therapy. Science 262: 1011-1018.

Fauci AS 1996. Host factors and the pathogenesis of HIV-induced disease. Nature 384: 529-533.

Ferbas J 1998. Perspectives on the role of CD8 and factors and cytotoxic T lymphocytes during HIV infection. Aids Res Hum Retrov 14: S153-160.

Finzi D, Hermankova M, Pierson T, Carruth LM, Buck C, Chaisson RE, Quinn TC, Chadwick K, Margolick J, Brookmeyer R, Gallant J, Markowitz M, Ho DD, Richman DD, Siliciano RF 1997. Identification of a reservoir for HIV-1 in patients on highly active antiretroviral therapy. Science 14: 1295-1300.

Garvy BA, Telford WG, King LE, Fraker PJ 1993. Glucocorticoids and irradiation-induced apoptosis in normal murine bone marrow B-lineage lymphocytes as determined by flow cytometry. Immunology 79: 270277.

Gougeon ML, Lecoeur H, Sasaki Y 1999. Apoptosis and the CD95 system in HIV disease: impact of highly active anti-retroviral therapy. Immunol Lett 66: 97-103. 
Graziosi C, Soudeyns H, Rzzardi P, Bart PA, Chapuis A, Pantaleo G 1998. Immunopathogenesis of HIV Infection. Aids Res Hum Retrov 14: S135-142.

Guideline for clinical treatment of HIV infection in children 1998. National Coordination of STD and Aids, Brazilian Ministry of Health, in portuguese.

Hamel W, Dazin P, Israel MA 1996. Adaptation of a simple flow cytometric assay to identify different stages during apoptosis. Cytometry 25: 173-181.

Johnson D, Hirschkorn D, Bush MP, and the National Heart, Lung, and Blood Institute Retrovirus Epidemiology Donor Study 1995. Evaluation of four alternative methodologies for determination of absolute CD4 ${ }^{+}$lymphocyte counts. JAIDS 10: 522-530.

Kestens L, Vanham G, Gigase P, Young G, Hannet I, Vanlangendonck F, Hulstaert F 1992. Expression of activation antigens, HLA-DR and CD38, on CD8 lymphocytes during HIV-1 infection. Aids 6: 793-797.

Krouwels FH, Nocker RE, Snoek M, Lutter R, van der Zee JS, Weller FR, Jansen HM, Out TA 1997. Immunocytochemical and flow cytofluorimetric detection of intracellular IL-4, IL-5 and IFN-gamma: applications using blood- and airway-derived cells. J Immunol Methods 203: 89-101.

Laffeuillade A, Chouraqui M, Hittinger G, Poggi C, Delbeke E 1997. Lymph node expansion of CD4 ${ }^{+}$ lymphocytes during antiretroviral therapy. I Infec Dis 176: 1378-1382.

Landay A, Ohlsson-Wilhelm B, Giorgi JV 1990. Application of flow cytometry to the study of HIV infection. Aids 4: 479-97.

Laurence J 1993. T-cell subsets in health, infectious disease, and idiopathic CD4 ${ }^{+} \mathrm{T}$ lymphocytopenia. Ann Intern Med 119: 55-62.

Levy JA, Mackewicz CE, Barker E 1996. Controlling HIV pathogenesis: the role of the noncytotoxic antiHIV response of $\mathrm{CD}^{+} \mathrm{T}$ cells. Immunol Today 17: 217-24.

Mccloskey TW, Oyaizu N, Pahwa S 1995. Expression of the antigen patients infected with human immunodeficiency virus. Cytometry 15: 111-114.

Mccloskey TW, Oyaizu N, Pahwa S 1998. CD95 Expression and apoptosis during pediatric HIV infection: early upregulation of CD95 expression. Clin Immunol Immunopathol 87: 33-41.

Mellors JW, Munoz A, Giorgi JV, Margolick JB, Tassoni CJ, Gupta P, Kingsley LA, Todd JA, Saah AJ, Detels R, Phair JP, Rinaldo Jr CR 1997. Plasma viral load and $\mathrm{CD}^{+}$lymphocytes as prognostic markers of HIV-1 infection. Ann Intern Med 126: 946-954.

Mellors JW, Rinaldo Jr CR, Gupta P, White RM, Todd JÁ, Kingsley LA 1996. Prognosis of HIV-1 infection predicted by the quantity of virus in plasma. Science 272: 1167-1170.

Ministério da Saúde 1998. Brazilian STD/Aids Program (http://www.aids.gov.br).

Neves Jr. I, Bertho AL, Gonçalves VSV, Nascimento DV, Campos-Mello DLA, Morgado MG 1998. Improvement of the lymphoproliferative immune response and apoptosis inhibition upon in vitro treatment with zinc of PBMC from HIV positive individuals. Clin Exp Immunol 111: 264-268.

Ogg GS, Jin X, Bonhoeffer S, Dunbar PR, Nowak MA,
Monard S, Segal JP, Cao Y, Rowland-Jones SL, Cerundolo V, Hurley A, Markowitz M, Ho DD, McMichael AJ 1998. Quantitation of HIV-1 specific cytotoxic T lymphocytes and plasma load of viral RNA. Science 279: 2103-2106.

Pantaleo G 1997. How immune-based interventions can change HIV therapy. Nature Med 3: 483-486.

Pantaleo G, Fauci A 1996. Immunopathogenesis of HIV infection. Ann Rev Microbiol. 50: 825-54.

Pantaleo G, Demarest JF, Soudeyns J, Graziosi C, Denis F, Adelsberger JW, Borrow P, Saag MS, Shaw GM, Sekaly RP, Fauci AS 1994. Major expansion of $\mathrm{CD}^{+} \mathrm{T}$ lymphocytes with a predominant V $\beta$ usage during primary immune response to HIV. Nature 370 : 463-467.

Pantaleo G, Demarest JF, Schacker T, Vacarezza M, Cohen JM, Daucher MB, Graziosi C, Schnittman SM, Quinn TC, Shaw GM, Perrin L, Tambussi G., Lazzarin A, Sekaly RP, Soudeyns H, Corey L, Fauci AS 1997. The qualitative nature of the primary immune response to HIV infection is a prognosticator of disease progression independent of the initial level of plasma viremia. Proc Natl Acad Sci USA 94: 254-258.

Rabinovitch PS, Torres RM, Engle D 1986. Simultaneous cell cycle analysis and two-color surface immunofluorescence using 7 amino-actinomycin D and single laser excitation: applications to study of cell activation and cell cycle of murine Ly-1 B cells. J Immunol 136: 2769-2775.

Rosenberg E, Walker BD 1998. HIV type 1-specifics helper T cells: a critical host defense. Aids Res Hum Retrov 14: S143-147.

Rothen M, Gratzl S, Hirsch HH, Moroni C 1997. Apoptosis in HIV-infected individuals is na early marker occuring independently of high viremia. Aids Res Hum Retroviruses 10: 771-779.

Schmid I, Krall WJ, Uittenbogaart CH, Braun J, Giorgi JV 1992. Dead cell discrimination with 7-aminoactinomycin D in combination with dual color immunofluorescence in single laser flow cytometry. Cytometry 13: 204-208.

Schmid I, Krall WJ, Uittenbogaart CH, Braun J, Giorgi JV 1994. Sensitive method for measuring apoptosis and cell surface phenotype in human thymocytes by flow cytometry. Cytometry 15: 12-20.

Stellbrink HJ, Zoller B, Fenner T, Lichtenberg G, van Lunzen J, Albrecht H, Thiele HG, Greten H 1996. Rapid plasma virus and CD4+ T-cell turnover in HIV-1infection: evidence for an only transient interruption by treatment. Aids 10: 849-857.

Stites DP, Moss AR, Bacchetti P, Osmond D, McHugh TM, Wang YJ, Heber S , Colfer B 1989. Lymphocyte subset analysis to predict progression to Aids in a cohort of homosexual men in San Francisco. Clin Immunol Immunopathol 52: 96-103.

van Rood Y, Goulmy E, Blokland E, Pool J, van Rood J, van Houwelingen H 1991. Month-related variability in immunological test results; implications for immunological follow-up studies. Clin Exp Immunol 86: 349-354.

Walker CM, Levy JÁ 1989. A diffusible lymphokine produced by $\mathrm{CD}^{+} \mathrm{T}$ lymphocytes suppresses HIV replication. Immunology 66: 628-630. 